\title{
Perceived Effect of Households' Socio-economic Variables on the Academic Performance of Junior Secondary School Students in CCA in Maiduguri, Borno State, Nigeria
}

\author{
Kwando Alhassan Saidu ${ }^{1}$, Hajja Mama Ali ${ }^{2}$ \\ ${ }^{1}$ Department of Visual and Performing Arts, University of Maiduguri, Maiduguri, Nigeria \\ ${ }^{2}$ Department of Fine and Applied Arts, Umar Suleiman College of Education, Gashua, Nigeria
}

Email address:

kwandowuyo@gmail.com (K. A. Saidu)

\section{To cite this article:}

Kwando Alhassan Saidu, Hajja Mmama Ali. Perceived Effect of Households' Socio-economic Variables on the Academic Performance of Junior Secondary School Students in CCA in Maiduguri, Borno State, Nigeria. Education Journal. Vol. 7, No. 6, 2019, pp. 87-92. doi: $10.11648 /$ j.ijsts.20190706.12

Received: January 12, 2019; Accepted: March 30, 2019; Published: December 4, 2019

\begin{abstract}
The study examined the effects of households' socio-economic variables on junior secondary school students' academic performance in CCA in University of Maiduguri Demonstration Secondary School and El-Kanemi Islamic College of Theology, Maiduguri, Borno State, Nigeria. Survey and ex-post facto research design work was used to collect data on student socio-economic background and their academic performance respectively. Using stratified and purposive sampling techniques, 510 students and 5 CCA's teachers were selected. Structured questionnaires were used for data collection. Therefore, a total of 515 respondents formed the sample of the study. The data were analysed using inferential statistics to determine the effects of households' socio-economic variables on students' academic performance. Results from the study showed that households' socio-economic variables have significant effect on students' academic performance in CCA in University of Maiduguri Demonstration Secondary School and El-Kanemi Islamic College of Theology. Therefore, the researchers recommended that government should provide some incentives that will encourage more students to enroll for formal education, such as scholarships, provide free transportation to school for students, establish schools for adult education and encourage couples to imbibe family planning.
\end{abstract}

Keywords: Households, Socio-Economic Variables, Cultural and Creative Arts, Students' Academic Performance

\section{Introduction}

In Borno State, family and parents are responsible for financing their children's education. The type of education given to children depends on the financial status of the family. There has been a gap between the academic performances of students despite being taught the same course content by the same teacher in the same class in University of Maiduguri Secondary School. While it is the educator or the teacher who can know the latent faculties of the child and take appropriate methods to develop those powers [18], it is very likely that other external factors outside teachers' performance and quality of education provided in schools may influence a student's academic performance. A very good example of these external factors is parental socio-economic status.
Families from low social economic status communities are less likely to have the financial resource or time available to provide children with academic support. Family background is key to a students' life and outside of school, is the most important influence on student learning and includes factors such as socioeconomic status, two-parent versus singleparent households, divorce, parenting practices and aspirations, maternal characteristics, family size, and neighborhood [20]. The environment at home is a primary socialization agent and influences a child's interest in school and aspirations for the future.

A person's education is highly correlated to their socioeconomic status. Therefore, it is important to have a clear understanding of what benefits or hinders students' educational attainment. The socio-economic status (SES) of a child is most commonly determined by combining parents' 
educational level, occupational status, and income level [16]. Studies have repeatedly found that SES affects student outcomes [7, 16, 20, 11, 21, 27].

Students who have a low SES earn lower test scores and are more likely to drop out of school [11-15]. Low SES students have been found to score about ten percent lower on the National Assessment of Educational Programs than higher SES students [27]. SES has also been shown to override other educational influences such as parental involvement [21]. It is believed that low SES negatively affects academic achievement because low SES prevents access to vital resources and creates additional stress at home $[11,20,16]$. The economic hardships that are caused by low SES lead to disruptions in parenting, an increasing amount of family conflicts, and an increased likelihood of depression in parents and single-parent households [11]. For these reasons SES is closely tied to home environment and one could argue that SES dictates the quality of home life for children.

Previous research has shown that children from singleparent households do not perform as well in school as children from two-parent households [20]. There are several different explanations for this achievement gap. Single-parent households have less income and there is a lack of support for the single-parent which increases stress and conflicts [20]. Single parents often struggle with time-management issues due to balancing many different areas of life on their own. Some research has also shown that single-parents are less involved with their children and therefore give less encouragement and have lower expectations of their children than two-parent households [20].

Divorce has also been found to negatively affect academic achievement [16]. Students whose parents had divorced were among those who scored lowest on standardized test [16]. Possible explanations for this relationship are that divorce can cause a family's SES level to decrease and parental connections are harmed [16-20]. Research shows that supportive and attentive parenting practices positively affect academic achievement [11]. In addition, high parent aspirations have been associated with increasing students' interest in education [20]. The effect of parental involvement in their children's school has on academic achievement is less clear [21]. Parental involvement in school has been linked to both positive and negative influences on academic achievement [21]. Explanations for this discrepancy are not conclusive. It is thought that the type of involvement may make a difference and that in some cases parents become involved after their child has already had academic difficulties [21]. Other recent research has found more conclusively that while parental involvement may not help academic scores, it does help prevent behavioral problems [23].

Maternal characteristics are another key factor that affects academic achievement [7, 11, 20]. Mothers who are more educated and have higher self-esteem have children who receive higher test scores [7-11]. Also, mothers who delay childbearing have been shown to provide more "cognitively stimulating" and supportive environments at home which has a positive effect on school performance [11].

Smaller family size has been linked with higher academic achievement [19-20]. Students with fewer siblings are likely to receive more parental attention and have more access to resources than children from large families. The additional attention and support leads to better school performance [11$20]$.

Adolescents who live in higher quality neighborhoods typically perform better in school than those who live in poorer neighborhoods [11]. Poorer neighborhoods often lack positive role models, adult supervision, and connections to good schools [11]. That kind of environment often prevents students from creating healthy social networks and leads to a lack of motivation which negatively affects academic performance [11].

Socio-economic status had the greatest impact on students' test scores in relation to other variables in his study [8]. Parental background may have significant influence on students' academic achievement [22]. Children from low socio-economic environment acquire language skills more slowly and are at risk for reading difficulties [4]. Students' academic performance is predicted by a chain of socioeconomic factors resident in parents and some other persons [24].

After conducting a study on the effect of parasitic infections among school age children in Ilorin, concluded that academic performance of students is hindered in rural community where nutritional status is relatively low and health problems are prevalent. Nutritional status obviously is a function of parents' socio-economic status [2]. Socioeconomic status measures an individual in terms of occupation, education and income. Study on the relationship between a child's academic performance and parental occupation showed that when a child is ashamed of his parent's occupation, the child's attitude towards his parents and he would be adversely affected, thus impacting negatively on his academic performance [24]. Students from parents with formal occupation perform well than those from parents with informal occupation [33]. A positive relationship between the level of parental occupation and mean high-school marks of students in Lucknow district, India was observed [30]. Parents' occupation may have significant impact on children's performance [28].

Children from high income families were more likely to be proficient in reading tasks than children from low income families and parents in higher socio-economic status group were more likely to read to their children than were parents in the lower socio-economic status groups [9]. It was concluded after conducting a study with parents as respondents, that parents' family income may have significant on children's performance [28]. In a study of influence of family background on students' academic achievement found that students from high-income status parents achieve better academically [32].

Factors influencing academic performance of secondary 
school students in Pakistan and suggested that socioeconomic status and parents' education may have a significant effect on students' overall academic achievement as well as achievement in the subject of Mathematics and English [13]. High level educated parents to an extent have more influence on their children to achieve and perform well in their studies at secondary school level [17]. Students whose parents had higher educational levels performed higher on standardized tests than those who had parents with lower educational levels [14]. Parental educational level has a significant role in determining the educational achievement and social adjustment of the children [29]. Though parents' level of education affects children's academic performance, other variable such as school environment and facilities are also important [25].

In this study the researchers ascertained from secondary school teachers in Jere Local Government Area of Borno State, how socio-economic variable of their students' parents affect academic performance of their students.

\section{Definition of Terms}

i. Academic performance: A student's achievement, scores in tests and his position relative to all those subjected to the same test.

ii. Cultural and Creative Arts (CCA):- Programme used in the 9-year basic education in Nigeria which relates to arts and culture.

iii. Effect: The outcome of test, either positive or negative.

iv.Socio economic Variables: Gender, marital status, age, family type, household size, occupation, education and income of parents.

v. Student: A person who is enrolled in and attends an educational institution.

\section{Methodology}

For the study, nine independent variables were considered: - Gender, marital status, age, family type, household size, occupation, education and income of parents, while the dependent variable is students' academic performance.

$$
\mathrm{Zi}=\beta_{0}+\beta_{1} \mathrm{X}_{1}+\beta_{2} \mathrm{X}_{2}+\beta_{3} \mathrm{X}_{3}+\beta_{4} \mathrm{X}_{4}+\beta_{5} \mathrm{X}_{5}+\beta_{6} \mathrm{X}_{6}+\beta_{7} \mathrm{X}_{7}+\beta_{8} \mathrm{X}_{8}+\beta_{9} \mathrm{X}_{9}++\mathrm{U}
$$

Thus, the explanatory variables that would be included in the model are;

$\mathrm{X}_{1}=$ Age of Household Head (years) (AGE)

$\mathrm{X}_{2}=$ Gender of Household Head (GEND)

$\mathrm{X}_{3}=$ Marital status of Household Head

$\mathrm{X}_{4}=$ Types of family of Household Head

$\mathrm{X}_{5}=$ Household size (number)

$\mathrm{X}_{6}=$ Household Head's educational status (in years)

$\mathrm{X}_{7}=$ Household Head's Occupation

$\mathrm{X}_{8}=$ Household Head's income

1 if household head is male, 0 otherwise

0 if poor academic performance is caused by single parent, 1 otherwise.

1 if Household Head has one wife, 0 otherwise

0 if household size is $>5,1$ otherwise.

0 if Household Head's monthly income is $<\$ 50,000,1$ otherwise. 


\section{Data Analysis, Results and Discussion}

Table 1. Logistic Regression on Determinants of Academic Performance among Students in University of Maiduguri Demonstration Secondary School and El-Kanemi Islamic College of Theology.

\begin{tabular}{|c|c|c|c|c|c|c|}
\hline Variables & $\mathbf{B}$ & Standard Error & $\mathbf{Z}$ & p-value & Odd-Ratio & Result \\
\hline Age of household head $\left(X_{1}\right)$ & -0.0987 & 0.0246 & $-4.0122 * *$ & 0.000 & 1.342 & $\mathrm{~S}$ \\
\hline Gender of household head $\left(\mathrm{X}_{2}\right)$ & -0.8675 & 0.3601 & $-2.4091 * *$ & 0.013 & 0.231 & $\mathrm{~S}$ \\
\hline Marital Status of household head $\left(\mathrm{X}_{3}\right)$ & 0.5384 & 0.2512 & $2.1433 *$ & 0.001 & 0.427 & $\mathrm{~S}$ \\
\hline Family type $\left(\mathrm{X}_{4}\right)$ & 0.9659 & 0.2463 & $3.9216^{* *}$ & 0.012 & 0.998 & $\mathrm{~S}$ \\
\hline Household size $\left(\mathrm{X}_{5}\right)$ & 4.3908 & 0.3575 & $12.281 *$ & 0.000 & 1.606 & $\mathrm{~S}$ \\
\hline Level of education of household head $\left(\mathrm{X}_{6}\right)$ & 0.7867 & 0.2432 & $3.2348 * *$ & 0.011 & 1.235 & $\mathrm{~S}$ \\
\hline Occupation of household head $\left(\mathrm{X}_{7}\right)$ & 0.0311 & 0.0042 & $7.4048^{*}$ & 0.000 & 0.865 & $\mathrm{~S}$ \\
\hline Constant & -4.4824 & 1.6215 & $-2.7644 * *$ & 0.000 & 0.407 & \\
\hline Log likelihood & 85.6473 & & 0.572 & & & \\
\hline Chi-square & 57.2145 & & 508.442 & & & \\
\hline Pseudo $\mathrm{R}^{2}$ & 0.2650 & & & & & \\
\hline Number of observations & 525 & & & & & \\
\hline
\end{tabular}

Source: Survey data, $2019 *$ Significant at $5 \%$ level, **Significant at $1 \%$ level.

Table 1 shows the result of the logit regression on determinants of academic performance among students in University of Maiduguri Demonstration Secondary School and El-Kanemi Islamic College of Theology.

Age of the household head $\left(X_{1}\right)$

The age of the household head $\left(\mathrm{X}_{1}\right)$ plays a crucial role in determining the academic performance of students. Age was found to be significant at $1 \%$ level and negatively related to students' academic performance in University of Maiduguri Demonstration Secondary School and El-Kanemi Islamic College of Theology, Maiduguri, Borno State, Nigeria. The analysis shows that an increase in age of household head decreases the odds of parent conducting extra-moral classes for the children at home by $1.342 \%$. This is because old parents do not have the strength and energy to conduct extramoral classes for their children. This suggests that students from young family perform better than those from old family. This finding is in line with the work of.

\section{Gender of household head $\left(X_{2}\right)$}

Gender of household head $\left(\mathrm{X}_{2}\right)$ was found to be negative and significant at $1 \%$ level. The analysis shows that household headed by female decreases the odds of students performing in school by 0.231 . This suggests that male headed households are more involved in financial children education than their female counterparts. This could be because financing education is seen as the primary responsibility of the father in the study area. Traditional or cultural practices and beliefs in Nigeria, as in many regions of the world, demand that the roles and responsibilities of men and women are different.

\section{Marital Status of household head $\left(X_{3}\right)$}

The coefficient of marital status of household head $\left(\mathrm{X}_{3}\right)$ was positively related to students' academic performance and statistically significant at 5\% level. This implies that students with singled parents are less likely do well academically than students brought up by both parents. The analysis shows that an increase in the number of single parents increases the odds of students performing in school by $0.427 \%$. This suggests that children from single- parent households do not perform as well in school as children from two-parent households. Single-parent households have less income and there is a lack of support for the single-parent which increases stress and conflicts. Also, single-parents are less involved with their children and therefore give less encouragement and have lower expectations of their children than two-parent households. This finding is in line with the finding of [16] who found that students whose parents had divorced were among those who scored lowest on standardized test. Possible explanations for this relationship are that divorce can cause a family's SES level to decrease and parental connections are harmed.

Family Type $\left(X_{4}\right)$

Family type $\left(\mathrm{X}_{4}\right)$ was positive and statistically significant at $1 \%$. This implies that the type of family students emanate has significant influence on their academic performance. The analysis showed that increase in the number of polygamous family decreases the odds of been food performing by 0.998 . This could be because children from polygamous families are given less attention than those from monogamous family.

Household size $\left(X_{5}\right)$

Household size $\left(\mathrm{X}_{5}\right)$ was found to be significant at $5 \%$ level and positively related to students' academic performance. This may suggest that increase in household size will decrease students' academic performance by $0.881 \%$. This can be explained by the fact that students from large families were less likely to be proficient in reading tasks than children from small families. This is because parent with many children tend to have much financial responsibility that incapacitate them from clothing and providing special need of their children in school such as textbooks, school uniforms and good medical bills. Also, Smaller family size has been linked with higher academic achievement $[11,20]$. Students with fewer siblings are likely to receive more parental attention and have more access to resources than children from large families. The additional attention and support leads to better school performance. 


\section{Level of education of household head $\left(X_{6}\right)$}

Level of education of household head $\left(\mathrm{X}_{6}\right)$ was found to be significant at $1 \%$ level and positively related to students' academic performance. This may suggest that increase parent's level of education will increase students' academic performance by $1.235 \%$. This can be explained by the fact that educated parents tend to care for their children education than uneducated parents. This finding aligns with the finding of [14] who reported that students whose parents had higher educational levels performed higher on standardized tests than those who had parents with lower educational levels. [29] further corroborated that parental educational level has a significant role in determining the educational achievement and social adjustment of the children. [25] reported that though parents' level of education affects children's academic performance, other variable such as school environment and facilities are also important.

\section{Occupation of household head $\left(X_{7}\right)$}

Occupation of household head $\left(\mathrm{X}_{7}\right)$ was found to be positive and statistically significant at $5 \%$. This means that parents' occupation has significance influence on students' academic performance. Hence, households with good farming experience are likely to be more food secure than households with no or little farming experience. This may suggest that 1 unit increase in parents' occupation will increase students' academic performance by 0.865 . This implies that when a child is ashamed of his parent's occupation, the child's attitude towards his parents and he would be adversely affected, thus impacting negatively on his academic performance. The finding of [33] agrees with this finding by postulating that students from parents with formal occupation perform well than those from parents with informal occupation. [30] observed a positive relationship between the level of parental occupation and mean high-school marks of students in Lucknow district, India.

\section{Income of household head $\left(X_{8}\right)$}

Income of household head $\left(\mathrm{X}_{8}\right)$ was found to be negative and significantly related to with students' academic performance at $1 \%$. This suggests that income of household head has significance their children academic performance. This may suggest that 1 unit decrease in parents' income will decrease their children academic performance by $1.289 \%$. This can be explained by the fact that children from high income families were more likely to be proficient in reading tasks than children from low income families and parents in higher socio-economic status group were more likely to read to their children than were parents in the lower socio-economic status groups. This finding supports the finding of [28], who concluded after conducting a study with parents as respondents, that parents' family income may have significant on children's performance. [32] in his study of influence of family background on students' academic achievement found that students from high-income status parents achieve better academically.

\section{References}

[1] Adamu, S., \& Dikko, S. (2017). The influence of family socio-economic status on the academic achievement of secondary school students in computer studies in Bauchi metropolis of Bauchi State Nigeria. Impact: International Journal of Research in Humanities, Arts and Literature, 5 (7), 123-142.

[2] Adewale, A. M. (2002). Implication of parasitic infections on school performance among school-age children in Ilorin. Ilorin Journal of Science Education, Vol. 2, 78-81.

[3] Akhtar, Z., \& Niazi, H. K. (2011). The relationship between socioeconomic status and learning achievements of students at secondary school level. International Journal of Academic Research, Vol. 3, 956-961.

[4] Aikens, N. L., \& Barbarin, O. (2008). Socioeconomic differences in reading trajectories: The contribution of family, neighbourhood and school contexts. Journal of Educational Psychology, 100 (2), 235-251.

[5] Amoo, T. B. (2017). Perceived effects of parental socioeconomic status on students' academic performance among teachers in Odeda Local Government Area of Ogun State. Unpublished thesis at Faculty of Education, National Open University of Nigeria.

[6] Astuti, Y. (2017). Assessment Concept of Geographical Skills on Senior High School in Indonesia. American Journal of Educational Research, 5 (8), 879-886.

[7] Baharudin, Rozumah and Tom Luster. 1998. Factors related to the quality of the home environment and children's achievement. Journal of Family Issues. 19 (4), 375-403.

[8] Barry, J. (2006). The effect of socio-economic status on academic achievement. Retrieved from Wichita State University website, https://soar.wichita.edu/browse?value $=$ Barry $\% 2 \mathrm{C}+$ Jennifer\&t ype=author

[9] Coley, R. J. (2002). An uneven start: Indicators of inequality in school readiness. Educational Testing Service, Princeton, NJ.

[10] Downey, D. (1995). When bigger is not better: Family size, Parental resources and Children's Educational performance. American Sociological Review, 60 (5), 746-761.

[11] Eamon, Mary. Keegan. (2005). Socialdemographic, school, neighborhood, and parenting influences on academic achievement of Latino young adolescents. Journal of Youth and Adolescenc, 34 (2), 163-175.

[12] Ella, R. E., Odok, A. O., \& Ella, G. E. (2015). Influence of family size and family type on academic performance of students in Government in Calabar municipality, Cross River State, Nigeria. International Journal of Humanities Social Sciences and Education, 2 (11), 108-114.

[13] Farooq, M. S., Chaudhry, A. H., Shafiq, M., \& Berhanu, G. (2011). Factors affecting students' quality of academic performance: A case of secondary school level. Journal of Quality and Technology Management, 5 (2), 1-14.

[14] Gooding, Y. (2001). The relationship between parental educational level and academic success of College freshmen. Retrieved from Iowa State University website, http://lib.dr.iastate.edu.rtd/429 
[15] Hochschild, Jennifer L. 2003. Social Class in Public Schools. Journal of Social Issues 59 (4), 821-840.

[16] Jeynes, William H. (2002). Examining the effects of parental absence on the academic achievement of adolescents: the challenge of controlling for family income. Journal of Family and Economic Issues 23 (2).

[17] Khan, R., Iqbal, N., \& Tasneem, S. (2015). The influence of Parents Educational level on Secondary School Students Academic Achievement in District Rajanpur. Journal of Education and Practice, 6 (16), 76-79.

[18] Kumar, S., \& Ahmad, S. (2008). Meaning, Aims and Process of Education. Retrieved from University of Delhi website, https://sol.du.ac.in/mod/resource/view.php?id=2689

[19] Machebe, C., \& Ifelunni, C. (2014). Influence of parental socio-economic status on academic achievement of students in selected schools in Nigeria: A case study of Enugu State. Journal of Education and Practice, 5 (2), 105-110.

[20] Majoribanks, Kevin. 1996. Family Learning Environments ans Students' Outcomes: A Review. Journal of Comparitive Family Studies 27 (2), 373-394.

[21] McNeal, Ralph B. 2001. Differential effects of parental involvement on cognitive and behavioral outcomes by socioeconomic status. Journal os Socio-Economics 30 (2), 171.

[22] Muruwei, M. (2011). Parents' level of education and Senior Secondary Students' Academic Performance in English Language in Bayelsa State, Nigeria. Journal of Research in National Development, 9 (2), 302-305.

[23] Ogunshola, F. \& Adewale, A. (2012). The effects of parental socio-economic status on academic performance of students in selected schools in Edu Lga of Kwara State Nigeria. International Journal of Academic Research in Business and Social Sciences, 2 (7), 230-239.

[24] Osonwa, O. K., Adejobi, A. O., Iyam, M. A., \& Osonwa, R. H. (2013). Economic Status of parents, a determinant on academic performance of Senior Secondary School Students in Ibadan, Nigeria. Journal of Educational and Social Research, 3 (1), 115-122.
[25] Ozurumba, C. N., Briggs, A. E., Ebuara, V. O., \& Emanghe, E. E. (2007). Parents' education and students' performance in educational statistics at Federal Capital Territory, Abuja Nigeria. Journal of Research in National Development, 5 (2), $10-10$

[26] Rosado, C. (2000). The Meaning of Education or Why we do what we do? . Retrieved from http://www.rosado.net/articles.html

[27] Seyfried, Sherri. F. 1998. Academic achievement of African American preadolescents: The influence of teacher perceptions. American Journal of Community Psychology, 26 (3), 381-402.

[28] Shah, M., \& Anwar, M. (2014). Impact of Parent's occupation and family income on Children's performance. International Journal of Research, 1 (9), 606-612.

[29] Singh, A., \& Vyast, J. (2014). The influence of socio-econonic status of parents and home environment on the study habits and academic achievement of students. International Research Journals, 5 (9), 348-352.

[30] Sukhendra, L. (2015). Parental Occupation and Academic Achievement of High-School Students in India. The Journal of Educational Research, 60 (8), 359-362.

[31] Turan, S. (2011). Plato's concept of education in 'republic' and Aristotle's concept of education in politics. Education and Science, 36 (162), 31-38.

[32] Ugwuja, O. G. (2010). Influence of family background on the academic achievement of senior secondary school students in Nsukka educational zone of Enugu State. Department of Educational Foundations, Faculty of Education. University of Nigeria Nsukka. International Journal of Academic Research in Business and Social Sciences

[33] Usaini, M., \& Abubakar, N. (2015). The impact of parents' occupation on academic performance of secondary school students in Kuala Terengganu. Multilingual Journal of Education and Social Sciences, 3 (1), 112-120. 